\title{
Front Matter: Volume 9204
}

, "Front Matter: Volume 9204," Proc. SPIE 9204, Interferometry XVII:

Advanced Applications, 920401 (18 August 2014); doi: 10.1117/12.2076055

SPIE Event: SPIE Optical Engineering + Applications, 2014, San Diego, California, United States 


\title{
PROCEEDINGS OF SPIE
}

\section{Interferometry XVII: Advanced Applications}

\author{
Cosme Furlong \\ Christophe Gorecki \\ Peter J. de Groot \\ Erik L. Novak \\ Editors
}

\section{8-20 August 2014}

San Diego, California, United States

Sponsored and Published by

SPIE 
The papers included in this volume were part of the technical conference cited on the cover and title page. Papers were selected and subject to review by the editors and conference program committee. Some conference presentations may not be available for publication. The papers published in these proceedings reflect the work and thoughts of the authors and are published herein as submitted. The publisher is not responsible for the validity of the information or for any outcomes resulting from reliance thereon.

Please use the following format to cite material from this book:

Author(s), "Title of Paper," in Interferometry XVII: Advanced Applications, edited by Cosme Furlong, Christophe Gorecki, Peter J. de Groot, Erik L. Novak, Proceedings of SPIE Vol. 9204 (SPIE, Bellingham, WA, 2014) Article CID Number.

ISSN: 0277-786X

ISBN: 9781628412314

Published by

SPIE

P.O. Box 10, Bellingham, Washington 98227-0010 USA

Telephone +1 3606763290 (Pacific Time) · Fax +1 3606471445

SPIE.org

Copyright @ 2014, Society of Photo-Optical Instrumentation Engineers.

Copying of material in this book for internal or personal use, or for the internal or personal use of specific clients, beyond the fair use provisions granted by the U.S. Copyright Law is authorized by SPIE subject to payment of copying fees. The Transactional Reporting Service base fee for this volume is $\$ 18.00$ per article (or portion thereof), which should be paid directly to the Copyright Clearance Center (CCC), 222 Rosewood Drive, Danvers, MA 01923. Payment may also be made electronically through CCC Online at copyright.com. Other copying for republication, resale, advertising or promotion, or any form of systematic or multiple reproduction of any material in this book is prohibited except with permission in writing from the publisher. The CCC fee code is 0277-786X/14/\$18.00.

Printed in the United States of America.

Publication of record for individual papers is online in the SPIE Digital Library.

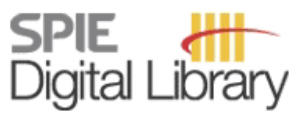

SPIEDigitalLibrary.org

Paper Numbering: Proceedings of SPIE follow an e-First publication model, with papers published first online and then in print and on CD-ROM. Papers are published as they are submitted and meet publication criteria. A unique, consistent, permanent citation identifier (CID) number is assigned to each article at the time of the first publication. Utilization of CIDs allows articles to be fully citable as soon as they are published online, and connects the same identifier to all online, print, and electronic versions of the publication. SPIE uses a six-digit CID article numbering system in which:

- The first four digits correspond to the SPIE volume number.

- The last two digits indicate publication order within the volume using a Base 36 numbering

system employing both numerals and letters. These two-number sets start with 00, 01, 02, 03, 04, $05,06,07,08,09,0 A, 0 B \ldots 0 Z$, followed by 10-1Z, 20-2Z, etc.

The CID Number appears on each page of the manuscript. The complete citation is used on the first page, and an abbreviated version on subsequent pages. Numbers in the index correspond to the last two digits of the six-digit CID Number. 


\section{Contents}

vii Conference Committee

SESSION 1 LIFE SCIENCE APPLICATIONS

920402 Microscopic contouring with low coherence interferometry endoscopy (Invited Paper) [9204-1]

B. Buckner, MetroLaser, Inc. (United States); B. Heeg, Lumium Optical Precision Instruments (Netherlands); T. Jenkins, J. Trolinger, MetroLaser, Inc. (United States)

920403 Endoscopic metrology for cardiovascular flows studies [9204-2]

L. Arévalo, E. Roche, V. Palero, N. Andrés, Univ. de Zaragoza (Spain); J. Lobera, Ctr. Univ. de la Defensa de Zaragoza (Spain); M. Á. Martínez, M. P. Arroyo, Univ. de Zaragoza (Spain)

920404 Shape and 3D acoustically induced vibrations of the human eardrum characterized by digital holography [9204-3]

M. Khaleghi, Worcester Polytechnic Institute (United States); C. Furlong, Worcester Polytechnic Institute (United States), Massachusetts Eye and Ear Infirmary (United States), and Harvard Medical School (United States); J. T. Cheng, J. J. Rosowski, Massachusetts Eye and Ear Infirmary (United States) and Harvard Medical School (United States)

920405 High-speed holographic system for full-field transient vibrometry of the human tympanic membrane [9204-4]

I. Dobrev, E. J. Harrington, Worcester Polytechnic Institute (United States); T. Cheng, Massachusetts Eye and Ear Infirmary (United States); C. Furlong, Worcester Polytechnic Institute (United States) and Massachusetts Eye and Ear Infirmary (United States); J. J. Rosowski, Massachusetts Eye and Ear Infirmary (United States) and MIT-Harvard Div. of Health Sciences and Technology (United States)

\section{SESSION 2 SURFACE SHAPE AND FORM}

920407 Artifact-free calibration of spatial carrier interferometry [9204-6]

B. Kimbrough, K. Prause, E. Novak, 4D Technology Corp. (United States)

920408 Absolute height measurement of specular surfaces with modified active fringe reflection photogrammetry [9204-7]

H. Ren, Univ. of Huddersfield (United Kingdom) and National Univ. of Defense Technology (China); X. Jiang, F. Gao, Univ. of Huddersfield (United Kingdom); Z. Zhang, Hebei Univ. of Technology (China)

920409 3D optical profilometry using a fiber optic Lloyd's mirror [9204-8]

T. Kart, G. Kosoglu, H. Yuksel, M. N. Inci, Bogaziçi Univ. (Turkey) 
9204 OA An asymmetric polarization-based frequency scanning interferometer: design principle [9204-9]

S. H. Lee, M. Y. Kim, Kyungpook National Univ. (Korea, Republic of)

9204 OB Dynamic shape measurements of rough surface with a two-wavelength method [9204-10] N. Andrés, L. A. Arévalo-Díaz, J. A. Lorda, V. Palero, Univ. de Zaragoza (Spain);

J. Lobera, Ctr. Univ. de la Defensa de Zaragoza (Spain); M. P. Arroyo, Univ. de Zaragoza (Spain)

\section{SESSION $3 \quad$ NOVEL METHODS AND APPLICATIONS}

9204 OC Advanced wave field sensing using computational shear interferometry (Invited Paper) [9204-11]

C. Falldorf, Bremer Institut für angewandte Strahltechnik GmbH (Germany); M. Agour, Aswan Univ. (Egypt); R. B. Bergmann, Bremer Institut für angewandte Strahltechnik GmbH (Germany)

9204 OD Simple setup for optical characterization of microlenses [9204-12] S. Perrin, M. Baranski, N. Passilly, L. Froehly, J. Albero, S. Bargiel, C. Gorecki, FEMTO-ST, CNRS, Univ. de Franche Comté (France)

9204 OE Dynamic temperature field measurements using a polarization phase shifting technique [9204-13]

D. I. Serrano-García, Utsunomiya Univ. (Japan); A. Martínez-García, Ctr. de Investigaciones en Óptica, A.C. (Mexico); N.-I. Toto-Arellano, Univ. Tecnológica de Tulancingo (Mexico); Y. Otani, Utsunomiya Univ. (Japan)

9204 OF Speckle interferometry at 10 micrometers wavelength: a combined thermography and interferometry technique and its application in aeronautical nondestructive testing [9204-14]

M. P. Georges, J.-F. Vandenrijt, C. Thizy, Univ. de Liège (Belgium); I. Alexeenko, G. Pedrini, Univ. Stuttgart (Germany); J. Rochet, OPTRION SA (Belgium); B. Vollheim, InfraTec GmbH (Germany); I. Jorge, I. López, Fundación Ctr. de Tecnologías Aeronáuticas (Spain); W. Osten, Univ. Stuttgart (Germany)

9204 OG Comparison of phase retrieval techniques based on the transport of intensity equation using equally and unequally spaced plane separation criteria [9204-15]

J. Martinez-Carranza, K. Falaggis, M. Jozwik, T. Kozacki, Warsaw Univ. of Technology (Poland)

\section{SESSION 4 INDUSTRIAL AND LARGE-SCALE METROLOGY}

$9204 \mathrm{OH} \quad$ Adding baselines at the Navy Precision Optical Interferometer [9204-16] J. R. Andrews, J. Clark, S. R. Restaino, J. T. Armstrong, H. Schmitt, E. K. Baines, U.S. Naval Research Lab. (United States); D. J. Hutter, J. A. Benson, B. T. Zavala, U.S. Naval Observatory (United States) 
9204 Ol Small pitch fringe projection method with multiple linear fiber arrays for 3D shape measurement [9204-25]

T. Hayashi, M. Fujigaki, Y. Murata, Wakayama Univ. (Japan)

9204 OK Glass bottle inspection by using digital in-line holography [9204-19]

P. Buranasiri, S. Plaipichit, King Mongkut's Institute of Technology Ladkrabang (Thailand)

POSTER SESSION

$92040 M \quad$ Study of the stability and uncertainty of an external cavity diode laser through a Michelson wavemeter [9204-20]

I. Outumuro, J. L. Valencia, Lab. Oficial de Metroloxia de Galicia (Spain); J. Diz-Bugarin,

J. Blanco, B. V. Dorrío, Univ. de Vigo (Spain)

9204 ON MG63 cells behavior on rough polypyrrole scaffolds investigated by digital holographic microscopy [9204-21]

M. Mihailescu, Univ. Politehnica of Bucharest (Romania); A. Matei, National Institute for Lasers, Plasma and Radiation Physics (Romania); A. Acasandrei, National Institute for Physics and Nuclear Engineering (Romania); R. C. Popescu, Univ. Politehnica of Bucharest (Romania); I. A. Paun, Univ. Politehnica of Bucharest (Romania) and National Institute for Lasers, Plasma and Radiation Physics (Romania); M. Dinescu, National Institute for Lasers, Plasma and Radiation Physics (Romania)

9204 OQ Blade counting tool with a 3D borescope for turbine applications [9204-24]

K. G. Harding, GE Global Research (United States); J. GU, L. Tao, GE Global Research (China); G. Song, GE Global Research (United States); J. Han, GE Global Research (China)

9204 OR A novel method for holographic femtosecond laser parallel processing using digital blazed grating and the divergent spherical wave [9204-26]

C. Wang, Y. Su, J. Wang, Anhui Univ. (China); C. Zhang, Univ. of Science and Technology of China (China); Z. Zhang, Anhui Univ. (China); J. Li, Univ. Of Science and Technology of China (China)

Author Index 


\section{Conference Committee}

Program Track Chairs

Katherine Creath, Optineering (United States) and The Univ. of

Arizona (United States)

Conference Chairs

Cosme Furlong, Worcester Polytechnic Institute (United States)

Christophe Gorecki, FEMTO-ST (France)

Peter J. de Groot, Zygo Corporation (United States)

Erik L. Novak, 4D Technology Corporation (United States)

Conference Program Committee

Armando Albertazzi Gonçalves Jr., Universidade Federal de Santa Catarina (Brazil)

Anand K. Asundi, Nanyang Technological University (Singapore)

Ralf B. Bergmann, Bremer Institut für angewandte Strahltechnik GmbH (Germany)

Katherine Creath, Optineering (United States) and The University of Arizona (United States)

Konstantinos Falaggis, Warsaw University of Technology (Poland)

Claas Falldorf, Bremer Institut für angewandte Strahltechnik GmbH (Germany)

Ángel M. Fernandez Doval, Universidade de Vigo (Spain)

Pietro Ferraro, Istituto Nazionale di Ottica (Italy)

Mauricio Flores Moreno, Centro de Investigaciones en Óptica, A.C. (Mexico)

Motoharu Fujigaki, Wakayama University (Japan)

James G. Fujimoto, Massachusetts Institute of Technology (United States)

Daniel R. Guildenbecher, Sandia National Laboratories

(United States)

Bradley T. Kimbrough, 4D Technology Corporation (United States)

Małgorzata Kujawińska, Warsaw University of Technology (Poland)

Fernando Mendoza Santoyo, Centro de Investigaciones en Óptica,

A.C. (Mexico)

Gunther Notni, Fraunhofer-Institut für Angewandte Optik und

Feinmechanik (Germany)

Wolfgang Osten, Institut für Technische Optik (Germany)

Ryszard J. Pryputniewicz, Worcester Polytechnic Institute (United States) 
Christian Rembe, Polytec GmbH (Germany)

Mikael Sjödahl, Luleå University of Technology (Sweden)

Pierre R. L. Slangen, Mines Alès (France)

James D. Trolinger, MetroLaser, Inc. (United States)

Rainer Tutsch, Technische Universität Braunschweig (Germany)

Wei-Chung Wang, National Tsing Hua University (Taiwan)

James C. Wyant, College of Optical Sciences, The University of Arizona (United States)

\section{Session Chairs}

$1 \quad$ Life Science Applications

Cosme Furlong, Worcester Polytechnic Institute (United States)

2 Surface Shape and Form

Erik L. Novak, 4D Technology Corporation (United States)

3 Novel Methods and Applications

Christophe Gorecki, FEMTO-ST (France)

4 Industrial and Large-scale Metrology

Peter J. de Groot, Zygo Corporation (United States) 